\title{
Denis Earp: a lifetime in dam engineering
}

Rachel Pether MEng, CEng, FICE

Project Director, Black \& Veatch Ltd (petherr@bv.com)

Denis Earp has been one of the UK's longest serving and most prolific panel engineers, undertaking 330 reservoir inspections during 30 years of continuous appointment to the panel. In the 1980s, he inspected every single reservoir owned at that time by the predecessor of Dŵr Cymru Welsh Water. I interviewed Denis at his home in Swansea, where he lives with his wife Jean.

\section{Early career in Iraq}

Shortly before graduating from Cambridge University in 1952, Denis Earp accepted a position as a graduate engineer at Binnie \& Partners, and subsequently received a letter from Senior Partner Geoffrey Binnie, enquiring as to whether he had an interest in irrigation and would like to start work in the Iraqi capital of Baghdad (Figure 1). Denis cycled the 60 miles from Cambridge to London for an interview with Geoffrey Binnie, and was accepted for the role. It was only later that he found out that of the 20 graduates that Binnie approached for the posting, Denis was the only one who had expressed any interest.

Denis's first posting in Baghdad was spent building physical models of a proposed barrage on the Lower Zab. His British line manager decamped after 3 months due to the hot weather, leaving Denis as the sole European in charge of a 100 strong team of locals, only two of whom spoke English. The barrage was sadly never built, and after 14 months, Denis returned to the United Kingdom for a short period. It was at this stage that his employer rather belatedly decided that Denis should attend evening classes to learn Arabic. However he soon proved unpopular with the tutor for introducing his self-taught Baghdadi slang Arabic into the classroom.

While back in the United Kingdom, Denis married his first wife Audrey, and they set off to Iraq again the day after their wedding, travelling by train across Europe. Audrey had previously worked as a teacher in the United Kingdom, but learnt to be a surveyor and worked alongside Denis on site. They remained in Iraq until 1960 working on a number of projects, the highlight of which was the construction of the Dokan dam, which is a $116.5 \mathrm{~m}$ high concrete arch dam on the Little $\mathrm{Zab}$ in northern Iraq.

\section{UK design and construction experience}

In 1960 Denis returned to the United Kingdom, still with Binnie \& Partners, and took up a position as deputy resident engineer during construction of Llyn Celyn in north Wales, which is a $51 \mathrm{~m}$ high embankment dam. This period of Denis's career proved frustrating, as the resident engineer for whom he worked was not inclined to delegate. Mainly for this reason, Denis left Binnies in 1962 and joined the South Staffordshire Waterworks (SSW) company.

The chief engineer and panel engineer at SSW at that time appeared to be a more enlightened manager, and gave Denis full responsibility for the design of SSW's new reservoir. Chelmarsh, which is a $27 \mathrm{~m}$ high embankment dam, was designed by Denis and two graduates under his direction in 8 months, and he then spent the following 3 years as resident engineer for the dam and associated pipework (Figure 2). I was particularly interested to hear about this dam, as I have been the supervising engineer for the reservoir for the past 2 years.

Changes in management led Denis to leave SSW in 1970, and take up a position as deputy chief engineer at the Colne Valley Water Company. While at Colne Valley, Denis was responsible for construction of a service reservoir in the grounds of Harrow school. Unfortunately during valve testing at the new reservoir, Denis flooded the outdoor swimming pool at the school, known as the Ducker. As a result he received a stern letter of complaint, addressed to a Mr TW Earp.

In 1974, after 4 years at Colne Valley, Denis went for an interview for a position at the West Glamorgan Water Board. Evidently, the interview panel was impressed, and offered him the job on the spot, on the condition that he decides then and there whether he would accept the position. He returned home that evening to advise his wife Jean that they would be moving to Swansea.

\section{Panel engineer appointment}

It was a year later in 1975 that Denis first applied to panel 1 under the 1930 Act, which was the equivalent of the All Reservoirs Panel under the Reservoirs Act (1975). Jean recalls how Denis returned to the United Kingdom early from a family holiday in France in order to attend his interview for appointment to the panel. However, he was surprised to be informed that he had been appointed to panel 2, which was the equivalent of the current non-impounding reservoirs panel, 


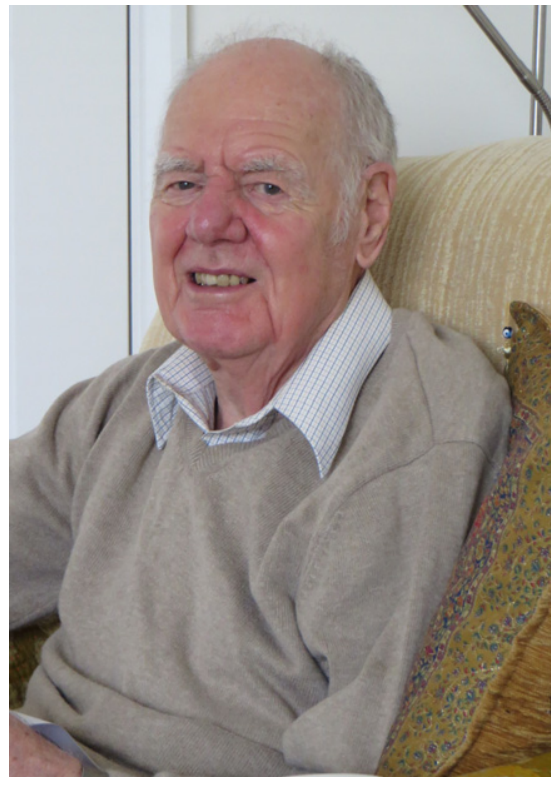

Figure 1. Denis Earp

despite the fact that the majority of his experience had been on impounding reservoirs. However he was soon moved up to panel 1.

In the 1980s, Denis was on the Reservoirs Committee and made recommendations to the Department of the Environment with regards to the implementation of the Reservoirs Act 1975, which finally took place in 1986. As a result of his efforts in this regard, the president of the Institution of Civil Engineers recommended him as a fellow of the Royal Academy of Engineering.

During a 30 year continuous period of appointment under the 1930 Act and then the 1975 Act, Denis has carried out 330 inspections in England, Scotland and Wales, and has witnessed many changes in our industry. The introduction of more stringent safety standards, and in particular confined space requirements, meant that crawling up 18 inch pipes for inspection, as Denis had done during the early years of his career, was no longer acceptable. Publication of the first edition of Floods and Reservoir Safety in 1978 led to a programme of spillway improvements as dams were subsequently reinspected in the 1980s. The volume definition of a large raised reservoir increased slightly from 5 million gallons $\left(22750 \mathrm{~m}^{3}\right)$ under the 1930 Act to $25000 \mathrm{~m}^{3}$ under the 1975 Act, and meanwhile the length of ten yearly inspection reports increased by a significantly greater margin.

Denis also remembers this time as a period of almost constant reorganisations, as the Glamorgan Water Board became

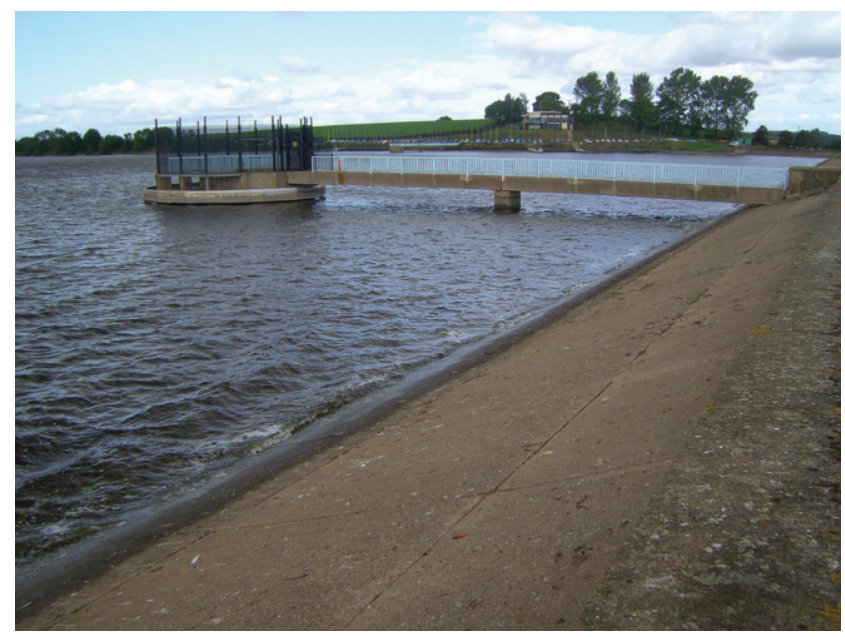

(a)

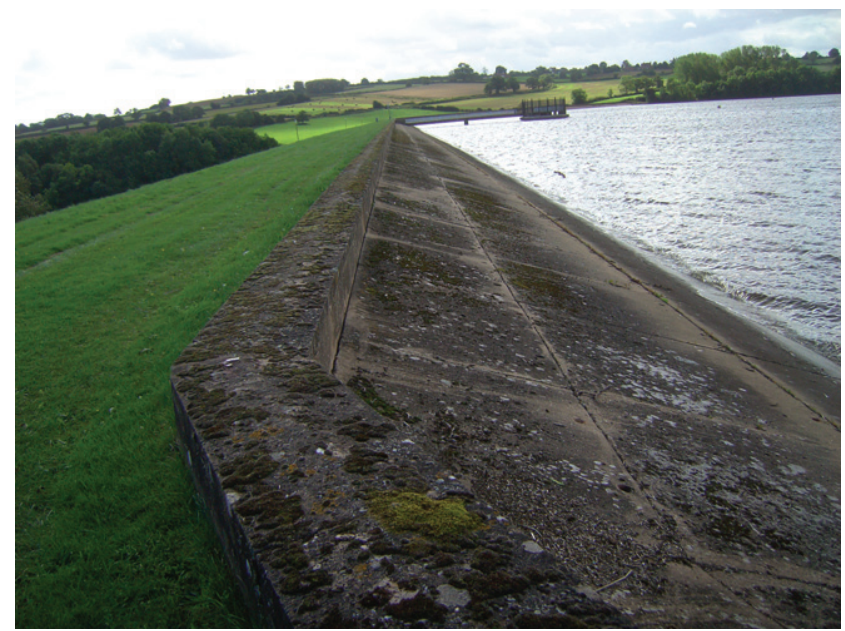

(b)

Figure 2. Chelmarsh Reservoir. (a) Overflow and (b) crest and upstream face

part of the Welsh National Water Development Authority, which would eventually become Dŵr Cymru Welsh Water (DCWW).

Under the 1975 Act, panel engineers are not permitted to inspect reservoirs owned by their employers. However under the 1930 Act, panel engineers could inspect reservoirs owned by their employer if they were responsible for the management of these assets. Spotting a loophole, the chief engineer for the newly formed National Authority appointed Denis as director of technical services for the whole of the organisation, but with no line management responsibilities. And so it was that Denis inspected every single one of the predecessor to DCWW's reservoirs during the 2 year period before the 1975 Act came into effect in 1986 (Figure 3). 


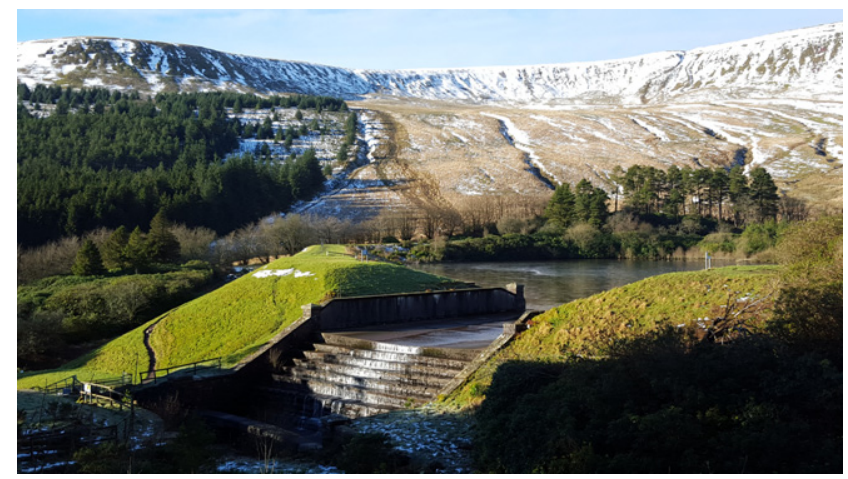

Figure 3. Lower Neuadd reservoir which is one of the numerous DCWW reservoirs that Denis inspected immediately prior to the implementation of the 1975 Act

Following implementation of the 1975 Act, Denis returned to Binnie \& Partners, based in their Chester office, and then in 1994 returned to Swansea as an independent consultant. During this period, Jean frequently accompanied Denis as he carried out inspections on many of the DCWW reservoirs that he had previously inspected under the 1930 Act, as well as other reservoirs across the United Kingdom. He also provided expert advice for a number of overseas projects, including several appointments for the World Bank and a brief involvement during the early stages of the construction of the Three Gorges project in China.

\section{Concluding remarks}

Throughout our interview it was clear that despite his age, Denis retains a curious mind, and he was keen to hear about the reservoirs for which I am supervising engineer, as well as current topics such as the number of female panel engineers who have been appointed to date, and the forthcoming conference in Swansea. We discussed many of the other dams that will appear in this special Welsh issue of Dams and Reservoirs, including Llyn Celyn for which he was deputy resident engineer, and Lluest Wen.

During the interview we flicked through a copy of Dams in the UK: 1963-1983 (ICE, 1983) to talk about some of the dams that Denis had worked on during his career, and I would recommend the publication to anybody who would like to learn more about the design and construction of modern dams in the United Kingdom. I was therefore both surprised and delighted at the end of the interview when Denis suggested that I keep his copy of the book.

Prior to interviewing Denis, I had suggested to him that it would be particularly interesting to hear about the changes that he had witnessed in the industry during his career. However, since conducting the interview, it has instead been the things that have stayed the same on which I have mainly reflected. Denis's achievements during a long and distinguished career are a testament to seizing opportunities enthusiastically, and overcoming challenges with similar determination, and ever thus shall be.

My thanks to Denis Earp for agreeing to the interview, and to his wife Jean Earp and also John Ackers, for their assistance both before and during the interview.

If you would like to propose an individual for interview in a future issue of Dams and Reservoirs, either from within our industry or beyond, then please contact us at editor@britishdams.org.

\section{How can you contribute?}

To discuss this paper, please email up to 500 words to the editor at editor@britishdams.org. Your contribution will be forwarded to the author(s) for a reply and, if considered appropriate by the editorial board, it will be published as discussion in a future issue of the journal. 